\title{
Sistem Rekomendasi Menggunakan Algoritma Apriori Pada Aplikasi E-Commerce Toko Sudirman Sport
}

\author{
Ahmad Sukanda \& Andri \\ Fakultas Teknik Ilmu Komputer, Universitas Bina Darma \\ Email: ahmadsukanda1234@gmail.com
}

\begin{abstract}
The System of selling and marketing products at the Sudirman Sport store which is still done conventionally causes the problem of lack of sales transactions obtained by the store because it only relies on buyers who come directly to the store. Meanwhile, many stores in Indonesia have implemented any system e-commerce in stores. The solution to this problem is to build a website-e-commerce application based for sales and marketing of products sold by the Sudirman Sport store and implement a marketing strategy, namely the System Recommendation Product attract buyers to buy products that have been offered by the Sudirman Sport store and combined with the a priori algorithm to get accuracy in the data processing process to help stores predict buyer interest in an item and then recommend it in order to attract buyers and increase product sales at the Sudirman sport store.
\end{abstract}

Keywords: e-commerce, recommendation system, apriori algorithm

\section{Pendahuluan}

Toko Sudirman sport merupakan sebuah toko yang menjual produk-produk olahraga seperti baju, celana, jaket, sepatu serta alat-alat olahraga diberbagai bidang yaitu Sepakbola, Bulutangkis, Voli, Renang, Lari, Futsal, sampai alat musik juga ada, Toko Sudirman Sport beralamat di Jl. Lintas Sumatera No.124 H, 17 Ilir, Kec. Ilir Tim. I, Kota Palembang, Sumatera Selatan. Toko Sudirman sport memiliki beberapa media sosial yang digunakan sebagai sarana publikasi informasi kepada pelanggan. Media sosial tersebut diantaranya Facebook, Instagram, Youtube. Pelanggan juga bisa mendapatkan informasi dengan datang langsung ke toko Sudirman sport. Informasi yang diproleh pelanggan dari media sosial tersebut juga mencakup informasi tentang toko dan juga informasi barangbarang apa saja yang dijual.

Pada era yang serba digital ini perkembangan e-commerce di indonesia telah diterima oleh masyarakat luas, hal ini merupakan kesempatan untuk sebuah pelaku e-commerce untuk bersaing di pasar dan juga untuk menarik lebih banyak lagi pembeli di tokonya. Sistem penjualan dan pemasaran produk di toko Sudirman sport yang masih dilakukan secara konvesional menyebabkan masalah menurunnya transaksi penjualan yang diperoleh toko dikarenakan hanya bertumpu kepada pembeli yang datang langsung ke toko. Sedangkan sudah banyak toko di Indonesia ini yang sudah menerapkan sistem $e$ commerce pada tokonya. Hal ini merupakan kesempatan yang bagus sekaligus menjadi tantangan tersendiri untuk menjadikan e-commerce sebagai media pemasaran dan penjualan online bagi para penjual di Indonesia untuk meningkatkan omset penjualan.

Solusi dari permasalahan menurunnya transaksi penjualan pada toko adalah dengan membangun aplikasi e-commerce berbasis web untuk pemasaran dan penjualan pada produk yang dijual toko Sudirman sport serta menerapkan strategi sistem rokomendasi yang digabungkan dengan metode algoritma apriori guna membantu toko untuk memprediksi minat pembeli pada suatu barang lalu merekomendasikannya demi menarik minat pembeli serta diharapkan akan meningkatkan pasar penjualan produk pada toko 
Sudirman dan juga dengan dibangunnya aplikasi e-commerce akan menjadi alat bantu yang mampu untuk menyediakan informasi produk maupun juga untuk mengolah sebuah informasi pada produk. Untuk itu akan lebih efektif jika data tersimpan dalam database dan disajikan didalam sistem website. Setiap data barang dapat diakses dan di kontrol dengan cepat kapanpun dan dimanapun pada saat data tersebut dibutuhkan.

Data penjualan yang terkumpul dan tersimpan pada database website maka dapat mempelajari transaksi penjualan pada toko Sudirman sport dan juga dapat diterapkan algoritma apriori yang dapat membantu untuk membentuk kandidat kombinasi item, kemudian dilakukan pengujian apakah kombinasi ini memenuhi parameter support dan confidence minimum yang merupakan nilai ambang yang diberikan. Dengan menggunakan algotitma apriori aplikasi e-commerce yang dibuat akan dapat memunculkan rekomendasi produk berdasarkan perhitungan nilai frequent suatu barang dengan produk dengan produk lainnya maka hasilnya dapat menjadi acuan untuk pengambilan keputusan untuk peningkatan penjualan produk-produk apa saja yang tepat untuk di rekomendasikan berdasarkan riwayar pembelian seluruh pelanggan.

\section{Tinjauan Review}

\subsection{Aplikasi}

Menurut Nazrudin Safaat H (2012) perangkat lunak aplikasi adalah suatu subkelas perangkat lunak komputer yang memanfaatkan kemampuan komputer untuk melakukan tugas yang diinginkan pengguna. Biasanya dibandingkan dengan perangkat lunak sistem yang mengintegrasikan kemampuan komputer, tapi tidak secara langsung menerapkan kemampuan tersebut untuk mengerjakan tugas yang menguntungkan pengguna. Menurut Jogiyanto yang dikutip oleh Ramzi (2013) aplikasi adalah penerapan, menyimpan sesuatu hal, data, permasalahan dan pekerjaan kedalam suatu sarana atau media yang bisa digunakan untuk menerapkan dan mengimplementasikan hal atau permasalahan yang ada sehingga berubah menjadi suatu yang baru tanpa menghilangkan nilai dasar dari hal data, permasalahan dan pekerjaan itu sendiri. Maka dari itu aplikasi adalah sebuah transformasi dari sebuah permasalahan atau sebuah pekerjaan yang sulit dipahami untuk menjadi lebih sederhana, dan mudah dipahami pengguna. Sehingga dengan adanya aplikasi, permasalahan akan terbantu lebih cepat dan tepat.

Aplikasi memiliki beberapa jenis, diantaranya aplikasi desktop yang beroperasi secara offline dan aplikasi web yang beroperasi secara online. Menurut Rouse yang dikutip oleh Ramzi (2013) aplikasi web adalah suatu program yang disimpan di server dan dikirim melalui internet dan diakses melalui antarmuka browser. Jadi aplikasi web merupakan aplikasi yang diakses menggunakan web browser melalui jaringan internet (secara online).

\subsection{E-Commerce}

Menurut Tata Sutabri (2012) Perdagangan elektronik atau e-dagang (bahasa inggris: Electronic Commerce atau E-Commerce) adalah penyebaran, pembelian, penjualan, pemasaran barang dan jasa melalui sistem elektronik seperti internet atau televisi, $w w w$ (World Wide Web), atau jaringan computer lainnya. Menurut Munir Fuady (2005) ECommerce juga dapat diartikan sebagai suatu proses berbisnis dengan memakai teknologi elektronik yang menghubungkan antara perusahaan dan konsumen dalam bentuk transaksi elektronik dan pertukuran/penjualan barang, servis, dan informasi secara 
elektronik.

\subsection{Data Mining}

Menurut Davies (2004) Data mining adalah penambangan atau penemuan informasi baru dengan mencari pola atau aturan tertentu dari sejumlah data yang sangat besar. Data mining disebut juga sebagai serangkaian proses untuk mendapatkan nilai tambah berupa pengetahuan yang tidak dapat diketahui secara manual dari suatu kumpulan data (Pramudiono, 2007). Data mining, sering juga disebut sebagai knowledge discovery in database (KDD). KDD merupakan kegiatan yang meliputi pengumpulan, pemakaian data, historis untuk menemukan keteraturan, pola dan hubungan dalam set data berukuran besar (Santoso, 2007).

\subsection{Algoritma Apriori}

Menurut Triyanto (2014) Algoritma apriori adalah suatu algoritma dasar yang diusulkan oleh Agrawal \& Srikant pada tahun 1994 untuk menentukan Frequent itemsets untuk aturan asosiasi Boolean. Algoritma apriori termasuk jenis Aturan Asosiasi pada data mining. Aturan yang menyatakan asosiasi antara beberapa atribut sering disebut affinity analysis atau market basket analysis. Association rule mining merupakan teknik data mining untuk mendapatkan aturan dari suatu kombinasi item. Salah satu tahap analisis asosiasi ialah untuk menghasilkan algoritma yang efisien adalah analisis pola frequensi tinggi (frequent pattern mining).

Ada dua ukuran ketertarikan dalam aturan asosiasi yaitu :

a. Support yaitu nilai penunjang atau presentase kombinasi sebuah item dalam database.

b. Confidence merupakan nilai kepastian yaitu kuatnya hubungan antar item dalam sebuah apriori. Confidence dapat dicari setelah pola frekuensi munculnya sebuah item ditemukan.

Rumus Perhitungan Support :

$$
\operatorname{Support}(A)=\frac{\text { Jumlah transaksi mengandung A }}{\text { Total transaksi }} \times 100 \%
$$

Rumus Perhitungan Confidence:

$$
\text { Confidence }=P(B \mid A)=\frac{\sum \text { Transaksi mendandung A dan } B}{\sum \text { Transaksi mengandung } A} \times 100 \%
$$

Langkah-langkah dalam algoritma apriori sebagai berikut :

1. Menguraikan masing-masing item dalam transaksi yang ada.

2. Menghitung jumlah banyaknya pembelian untuk setiap item.

3. Menentukan batas minimum transaksi.

4. Mengkombinasikan item-item, menghitung jumlah frekuensi transaksi kombinasi tersebut dan membandingkan dengan batas minimun transaksi.

5. Setelah menemukan kombinasi item yang memenuhi syarat minimum, kemudian menghitung nilai support dan confidence. 


\subsection{Sistem Rekomendasi}

Menurut Ricci et al (2011) sistem rekomendasi merupakan sebuah perangkat lunak yang bertujuan untuk membantu pengguna dengan cara memberikan rekomendasi kepada pengguna ketika pengguna dihadapkan dengan jumlah informasi yang besar. Rekomendasi yang diberikan diharapkan dapat membantu pengguna dalam proses pengambilan keputusan, seperti barang apa yang akan dibeli, buku apa yang akan dibaca, atau musik apa yang akan didengar, dan lainnya.

Sistem rekomendasi pribadi (personalized recommender system) harus mengenal terlebih dahulu setiap pengguna yang ada. Setiap dibangunnya sistem rekomendasi harus membangun dan juga memelihara user model atau user profile yang berisi ketertarikan pengguna sistem tersebut (Jannach et al, 2010). Sebagai contoh, sistem rekomendasi di website Amazon menyimpan setiap transaksi pembelian pelanggan, komentar pelanggan, dan review/rating yang diberikan oleh pelanggan terhadap suatu produk.

\subsection{Website}

Menurut M. Sandi (2014) Website merupakan suatu ruang informasi yang dipakai oleh pengguna global. Website sering dianggap sama dengan internet secara keseluruhan, walaupun sebenarnya hanyalah bagian daripada internet. Website adalah suatu sistem yang berkaitan dengan dokumen digunakan sebagai media untuk menampilkan teks, gambar, multimedia dan lainnya pada jaringan internet (Sibero, 2011).

\subsection{PHP Hypertext Preprocessor (PHP)}

Menurut Anhar (2010) PHP adalah script yang terintegrasi dengan HTML dan berada pada server (server side HTML embedded scripting). PHP merupakan script yang dapat digunakan untuk membuat halaman website yang lebih dinamis. Dinamis disini berarti halaman yang akan ditampilkan dibuat saat halaman itu diminta oleh client yang menggunakan sistem tersebut. Mekanisme ini dapat menyebabkan informasi yang diterima client selalu yang terbaru. Semua script PHP dieksekusi pada server yang dimana script tersebut dijalankan.

\subsection{Database}

Menurut Rosa dan salahuddin (2013) Database atau disebut basis data adalah media menyimpan data agar dapat diakses dengan mudah dan cepat. Sedangkan menurut Badiyanto (2013) Database adalah suatu kumpulan dari data yang tersimpan dalam tabel dan diorganisasikan sehingga data tersebut bisa diambil atau dicari dengan mudah dan efisien.

\subsection{XАMPP}

Menurut Yogi Wicaksono (2008 : 7) XAMPP merupakan sebuah software yang berfungsi untuk menjalankan website berbasis $P H P$ dan menggunakan pengolah data $M y S Q L$ dikomputer local. $X A M P P$ berperan sebagai server web pada komputer. $X A M P P$ juga disebut sebagai sebuah panel server virtual, yang bisa membantu melakukan preview sehingga dapat memodifikasi website tanpa harus online atau terakses dengan internet.

\subsection{MySQL}

Menurut Anhar (2010 : 45) MySQL merupakan salah satu databases management system (DBMS) dari sekian banyaknya DBMS seperti Oracle, $M S S Q L$, Postagre $S Q L$, dan 
lainnya. $M y S Q L$ dapat berfungsi sebagai pengelolah database menggunakan bahasa $S Q L$. $M y S Q L$ bersifat open source sehingga dapat digunakan secara gratis. Bahasa program $P H P$ juga mendukung atau mensupport dengan database $M y S Q L$.

\subsection{Metode Waterfall}

Menurut Pressman (2015) Metode waterfall merupakan model klasik yang bersifat secara sistematis, berurutan dalam membangun sebuah software. Model ini dapat melakukan pendekatan secara sistematis dan juga berurutan. Disebut waterfall dikarena tahap demi tahap yang dilalui harus menunggu selesainya tahap sebelumnya dan berjalan berurutan.

\subsection{Unified Modelling Language (UML)}

Menurut Sugiarti (2013) UML ialah sebuah bahasa yang telah menjadi standar dalam industri untuk visualisasi, merancang dan mendokumentasikan sistem piranti lunak. Menurut Rosa dan Salahudin (2013:133) UML (Unified Modeling Language) adalah salah satu standar bahasa yang banyak digunakan didunia industry untuk mendefinisikan requirement, membuat analisis \& desain serta menggambarkan arsitektur dalam pemograman berorientasi objek.

\subsubsection{Use Case Diagram}

Menurut Rosa dan Salahuddin (2013) Use Case atau Diagram Use Case merupakan pemodelan untuk sistem yang akan dibuat. Use Case mengdefinisikan dari sebuah intraksi antara satu atau lebih actor dengan sistem yang dibuat. Secara kasar, Use Case digunakan untuk mengetahuai fungsi apa saja yang ada didalam sebuah sistem informasi dan siapa saja yang berhak menggunakan fungsi-fungsi itu.

\section{Metode Penelitian}

\subsection{Aplikasi}

Menurut Jogiyanto yang dikutip oleh Ramzi (2013) aplikasi adalah penerapan, menyimpan sesuatu hal, data, permasalahan dan pekerjaan kedalam suatu sarana atau media yang bisa digunakan untuk menerapkan dan mengimplementasikan hal atau permasalahan yang ada sehingga berubah menjadi suatu yang baru tanpa menghilangkan nilai dasar dari hal data, permasalahan dan pekerjaan itu sendiri. Maka dari itu aplikasi adalah sebuah transformasi dari sebuah permasalahan atau sebuah pekerjaan yang sulit dipahami untuk menjadi lebih sederhana, dan mudah dipahami pengguna. Sehingga dengan adanya aplikasi, permasalahan akan terbantu lebih cepat dan tepat.

\subsection{E-Commerce}

Menurut Tata Sutabri (2012) Perdagangan elektronik atau e-dagang (bahasa inggris: Electronic Commerce atau E-Commerce) adalah penyebaran, pembelian, penjualan, pemasaran barang dan jasa melalui sistem elektronik seperti internet atau televisi, $w w w$ (World Wide Web), atau jaringan computer lainnya.

\subsection{Data Mining}

Menurut Davies (2004) Data mining adalah penambangan atau penemuan informasi baru dengan mencari pola atau aturan tertentu dari sejumlah data yang sangat besar. Data mining disebut juga sebagai serangkaian proses untuk mendapatkan nilai tambah berupa pengetahuan yang tidak dapat diketahui secara manual dari suatu kumpulan data.[3] Data 
mining, sering juga disebut sebagai knowledge discovery in database (KDD). KDD merupakan kegiatan yang meliputi pengumpulan, pemakaian data, historis untuk menemukan keteraturan, pola dan hubungan dalam set data berukuran besar.

\subsection{Algoritma Apriori}

Menurut Triyanto (2014) Algoritma apriori adalah suatu algoritma dasar yang diusulkan oleh Agrawal \& Srikant pada tahun 1994 untuk menentukan Frequent itemsets untuk aturan asosiasi Boolean. Algoritma apriori termasuk jenis Aturan Asosiasi pada data mining. Aturan yang menyatakan asosiasi antara beberapa atribut sering disebut affinity analysis atau market basket analysis. Association rule mining merupakan teknik data mining untuk mendapatkan aturan dari suatu kombinasi item. Salah satu tahap analisis asosiasi ialah untuk menghasilkan algoritma yang efisien adalah analisis pola frequensi tinggi (frequent pattern mining).

Ada dua ukuran ketertarikan dalam aturan asosiasi yaitu :

a. Support yaitu nilai penunjang atau presentase kombinasi sebuah item dalam database.

b. Confidence merupakan nilai kepastian yaitu kuatnya hubungan antar item dalam sebuah apriori. Confidence dapat dicari setelah pola frekuensi munculnya sebuah item ditemukan.

Rumus Perhitungan Support :

Support $(A)=\frac{\text { Jumlah transaksi mengandung A }}{\text { Total transaksi }} \times 100 \%$

Rumus Perhitungan Confidence:

Confidence $=P(B \mid A)=\frac{\sum \text { Transaksi mendandung A dan } B}{\sum \text { Transaksi mengandung } A} \times 100 \%$

\subsection{Sistem Rekomendasi}

Menurut Ricci et al (2011) sistem rekomendasi merupakan sebuah perangkat lunak yang bertujuan untuk membantu pengguna dengan cara memberikan rekomendasi kepada pengguna ketika pengguna dihadapkan dengan jumlah informasi yang besar. Rekomendasi yang diberikan diharapkan dapat membantu pengguna dalam proses pengambilan keputusan, seperti barang apa yang akan dibeli, buku apa yang akan dibaca, atau musik apa yang akan didengar, dan lainnya.

\subsection{Website}

Menurut M. Sandi (2014) Website merupakan suatu ruang informasi yang dipakai oleh pengguna global. Website sering dianggap sama dengan internet secara keseluruhan, walaupun sebenarnya hanyalah bagian daripada internet.

\section{Hasil dan Pembahasan}

\subsection{Tampilan Login Admin}

Pada halaman login harus memasukan username dan password. Halaman ini hanya dapat di akses oleh admin terlihat pada gambar 1 . 


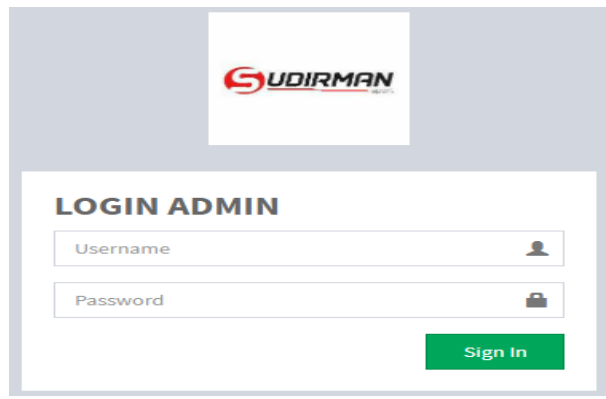

Gambar 1. Tampilan Login Admin

\subsection{Tampilan Dashboard Admin}

Pada halaman ini merupakan halaman dashboard. Halaman ini hanya dapat di akses oleh admin setelah melakukan login terlebih dahulu terlihat pada gambar 2 .

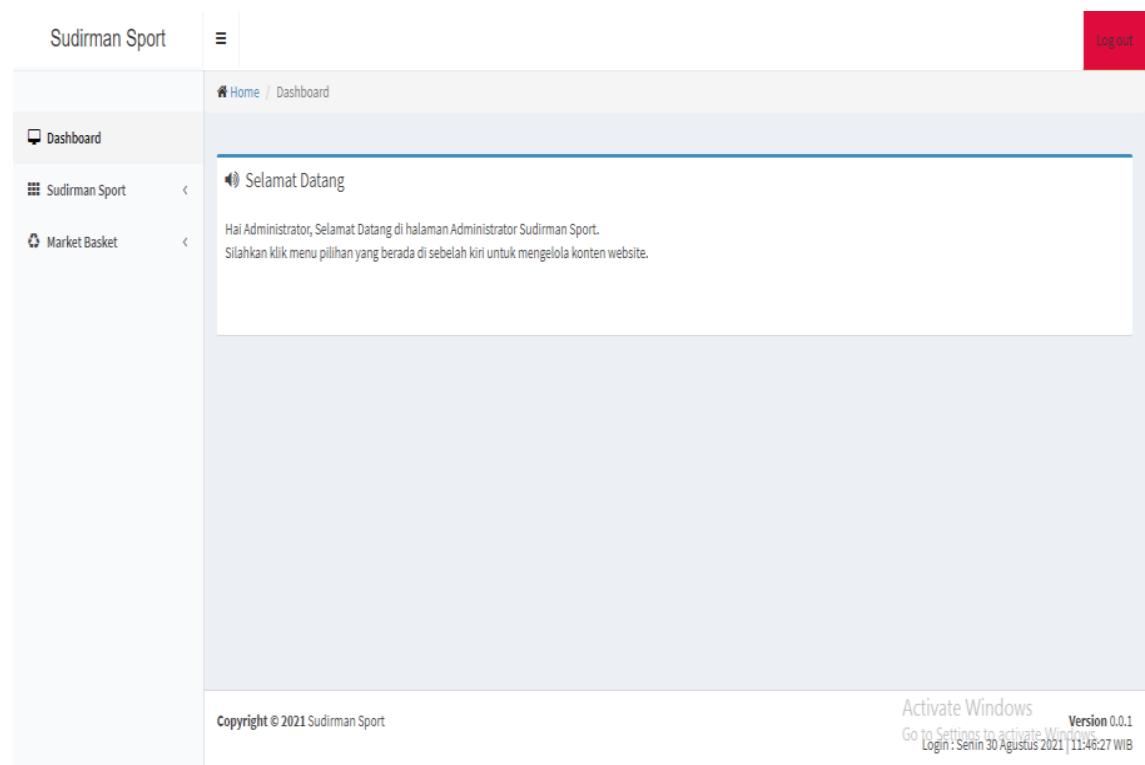

Gambar 2. Tampilan Dashboard Admin

\subsection{Tampilan Produk Admin}

Pada halaman ini admin dapat menambahkan, mengedit, menghapus data produk terlihat pada gambar 3 . 


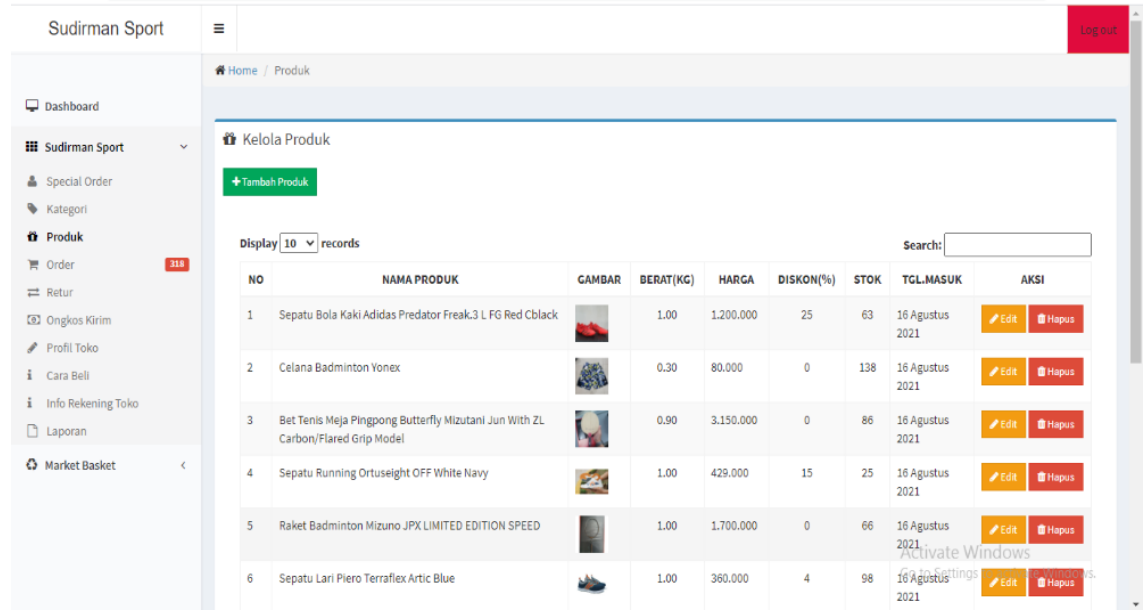

Gambar 3. Tampilan Produk Admin

\subsection{Tampilan Proses Apriori}

Pada halaman proses apriori, admin dapat melakukan proses pencarian hubungan antar barang berdasarkan tanggal transaksi penjualan dengan memasukan minimal support dan minimal confidence sebagai batasan dalam pencarian pola asosisasi menggunakan algoritma apriori. Di halaman ini di inputkan 20 data transaksi penjualan bulan agustus 2021 di toko Sudirman Sport dengan ketentuan untuk nilai minimun support 3\% dan nilai minimum confidence $50 \%$ terlihat pada gambar 4.

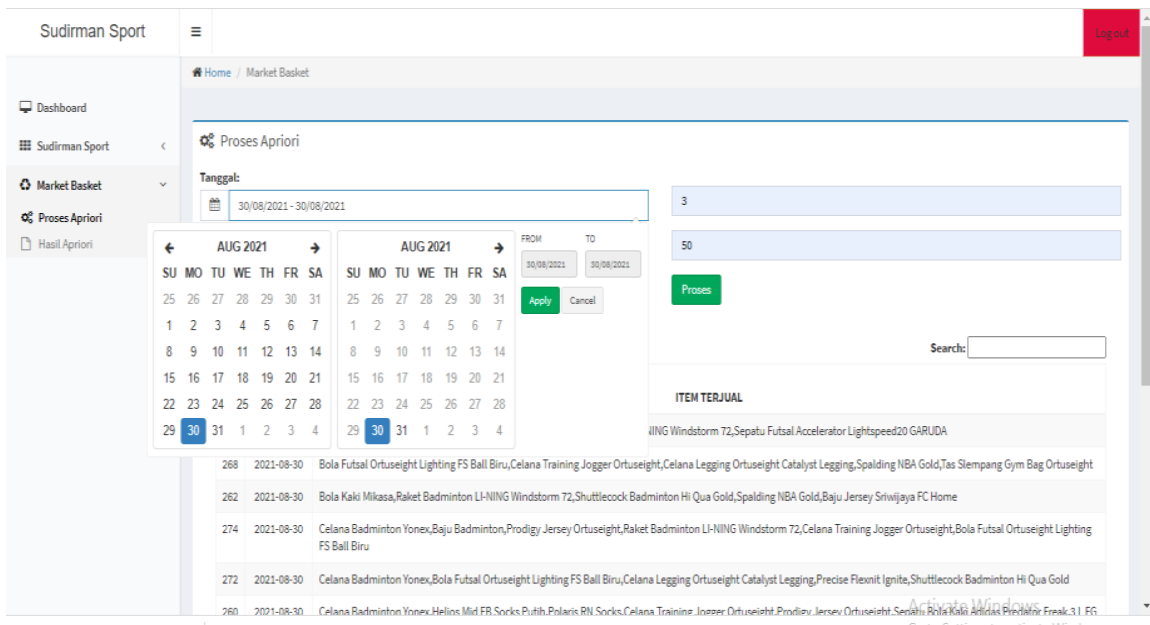

Gambar 4. Tampilan Proses Apriori

\subsection{Tampilan Hasil Apriori}

Pada halaman hasil apriori, admin dapat melihat tabel riwayat hasil dari proses apriori yang sudah dilakukan sebelumnya. Pada kolom status admin dapat melakuakan penerapan pola asosiasi dengan mengubah status dari nonaktif berganti menjadi aktif. Pada kolom aksi terdapat 2 kolom yaitu kolom lihat detail untuk melihat detail dari proses pencarian pola asosiasi dan kolom hapus untuk menghapus hasil dari proses apriori terlihat pada gambar 5. 


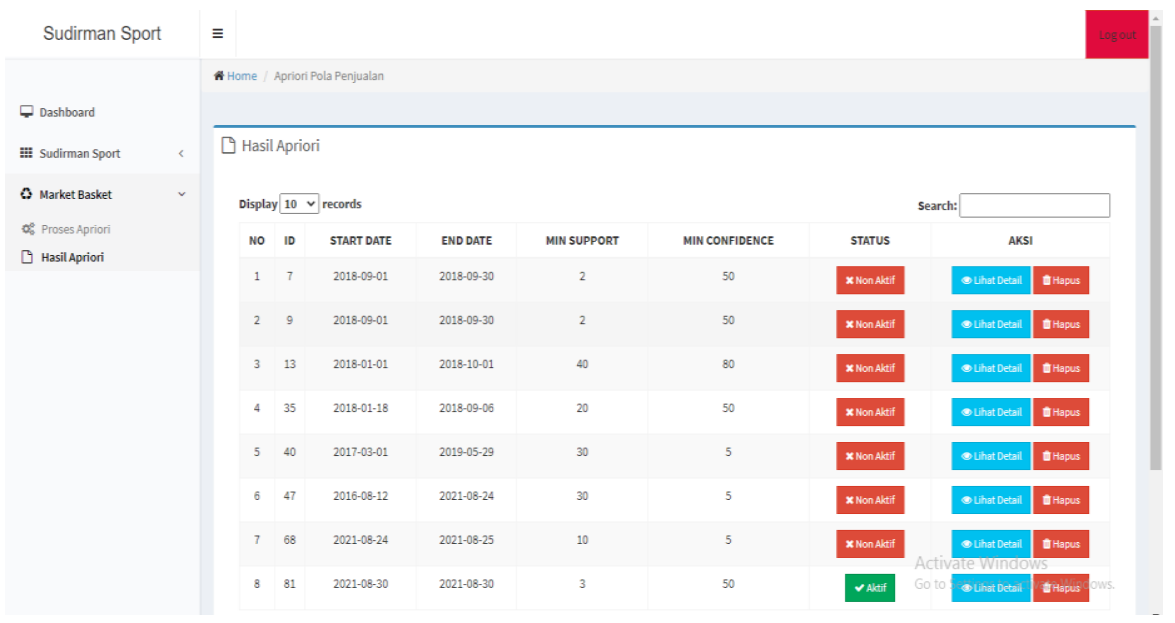

Gambar 5. Tampilan Hasil Apriori

Pada gambar 6. Merupakan hasil analisa pola belanja custumer, hasil dari proses analisis pola yang telah di inputkan dengan memberikan nilai minimum support $3 \%$ dan nilai minimum confidence $50 \%$ dari hasil analisis pola dihasilkan sebanyak 23 pola rule asosiasi yang didapatkan sebagai salah satu penjelasan ialah Precise Flexnit Ignite $==>$ Celana Leging Ortuseight Catalys Legging atau jika custumer membeli Precise Flexnit Ignite maka custumer $60 \%$ juga akan membeli Celana Leging Ortuseight Catalys Legging.

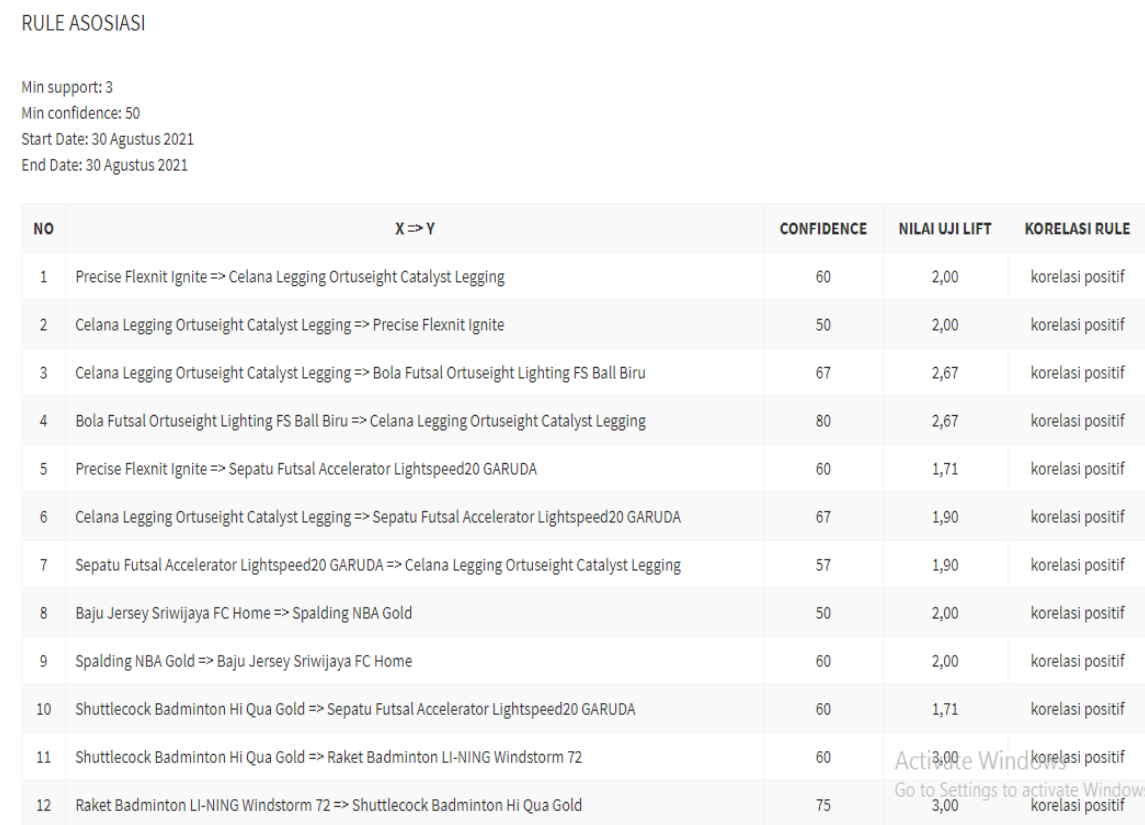

Gambar 6. Tampilan Detail Hasil Apriori 


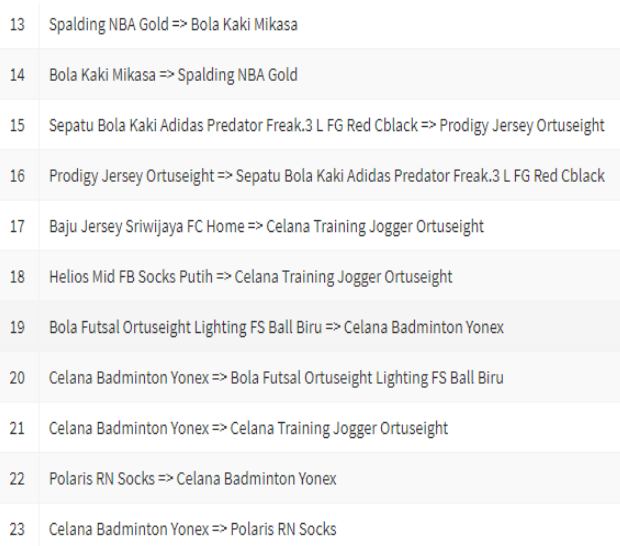

\begin{tabular}{|c|c|c|}
\hline 60 & 2,40 & korelasi positif \\
\hline 60 & 2,40 & korelasi positif \\
\hline 80 & 2,67 & korelasi positif \\
\hline 67 & 2,67 & korelasi positif \\
\hline 50 & 1,43 & korelasi positif \\
\hline 50 & 1,43 & korelasi positif \\
\hline 60 & 2,00 & korelasi positif \\
\hline 50 & 2,00 & korelasi positif \\
\hline 50 & 1,43 & korelasi positif \\
\hline 100 & $\begin{array}{l}\text { Acti } 3,36 \\
\text { Go to Sett }\end{array}$ & $\begin{array}{l}\text { Rorélasi positif } \\
\text { activate Windc }\end{array}$ \\
\hline 67 & 3,33 & korelasi positif \\
\hline
\end{tabular}

Gambar 7. Lanjutan Tampilan Detail Hasil Apriori

Dari hasil analisis pola pada gambar 6 dan 7 menunjukan bahwa nilai confidence yang semakin besar maka semakin besar juga kemungkinan produk yang direkomendasikan ketika custumer memilih produk tertentu berdasarkan kombinasi produk yang telah di proses berdasarkan data transaksi penjualan.

\subsection{Tampilan Login Customer}

Pada halaman login, customer harus melakukan login terlebih dahulu untuk memulai transaksi pembelian produk, jika customer belum memiliki akun dapat melakukan registrasi terlebih dahulu, /terlihat pada gambar 8.

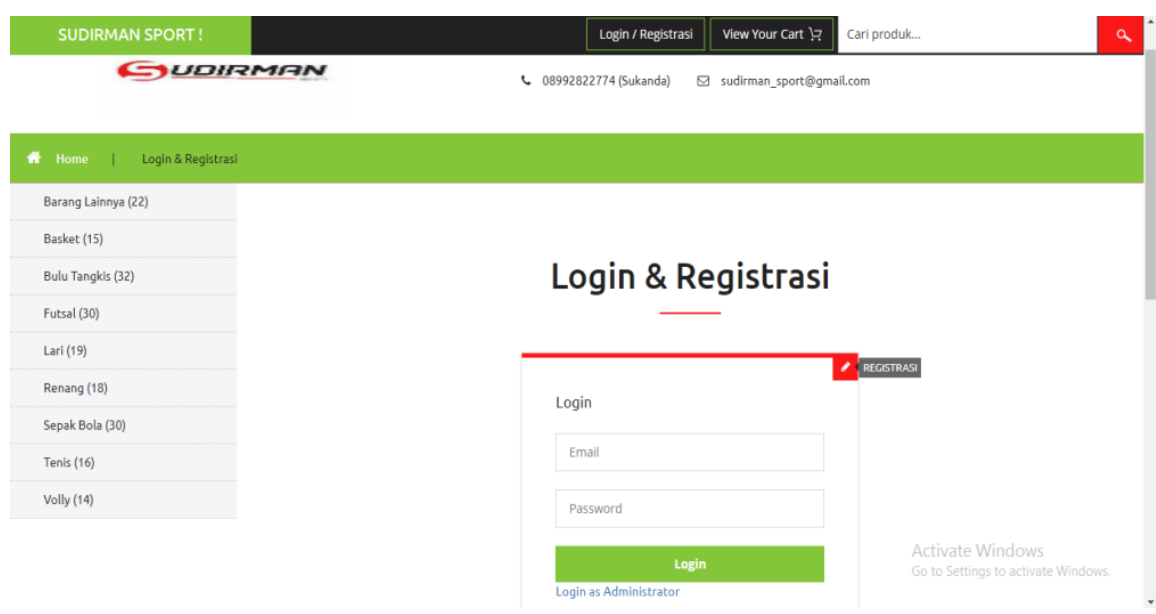

Gambar 8. Tampilan Login Customer

\subsection{Tampilan Dashboard Customer}

Pada halaman ini merupakan halaman dashboard customer terlihat pada gambar 9. 


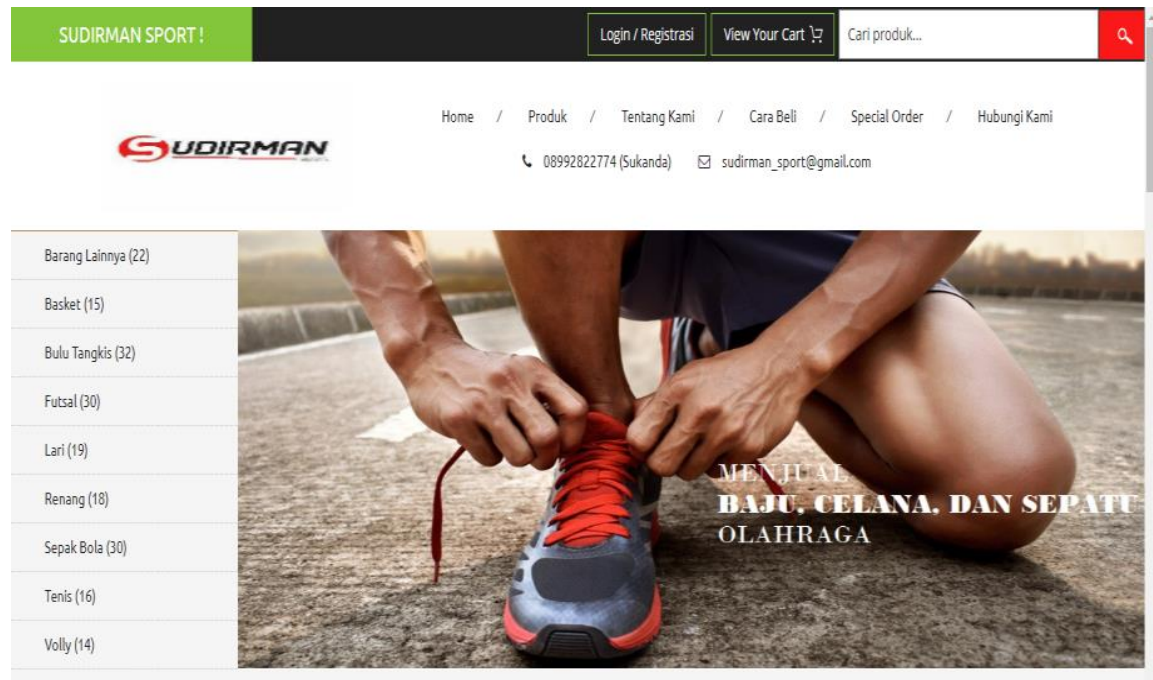

Gambar 9. Tampilan Dashboard Customer

\subsection{Tampilan Produk Customer}

Pada halaman ini. Pelanggan dapat melihat produk-produk apa saja yang di jual di Sudirman Sport. Pada halaman produk ini, tersedia berbagai macam peralatan dan perlengkapan olahraga terlihat pada gambar 10 .

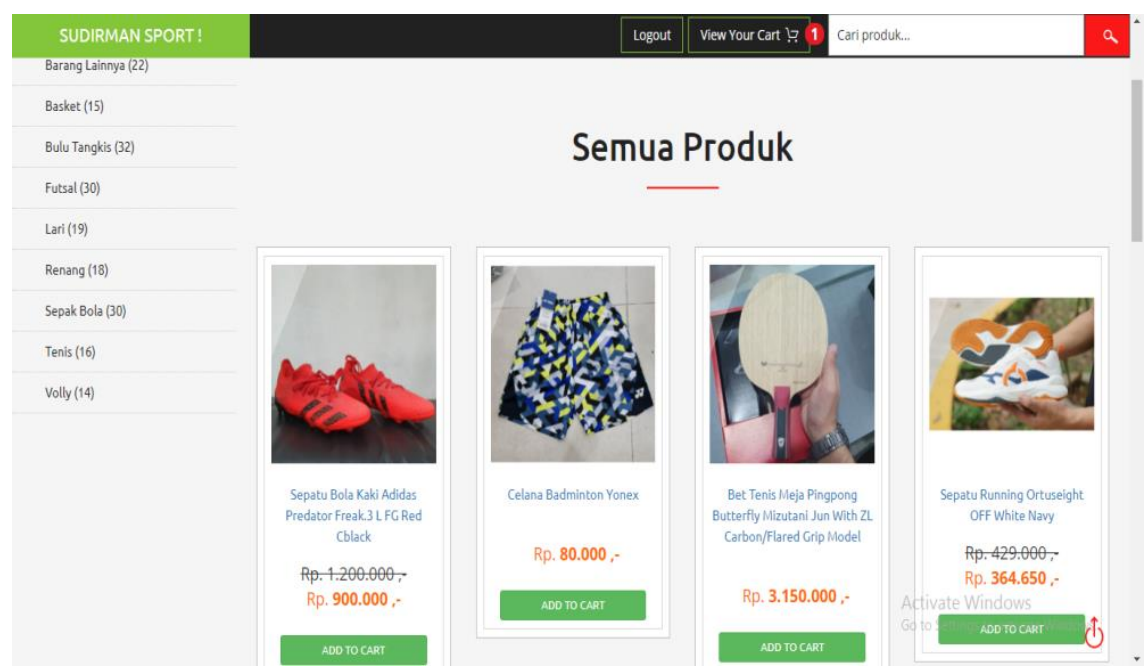

Gambar 10. Tampilan Produk Customer

\subsection{Tampilan Rekomendasi Apriori}

Pada Halaman ini berisikan informasi produk yang telah dimasukan kedalam keranjang belanja, dan daftar rekomendasi produk berdasarkan pola asosiasi yang sudah di dapatkan terlihat pada gambar 11 . 


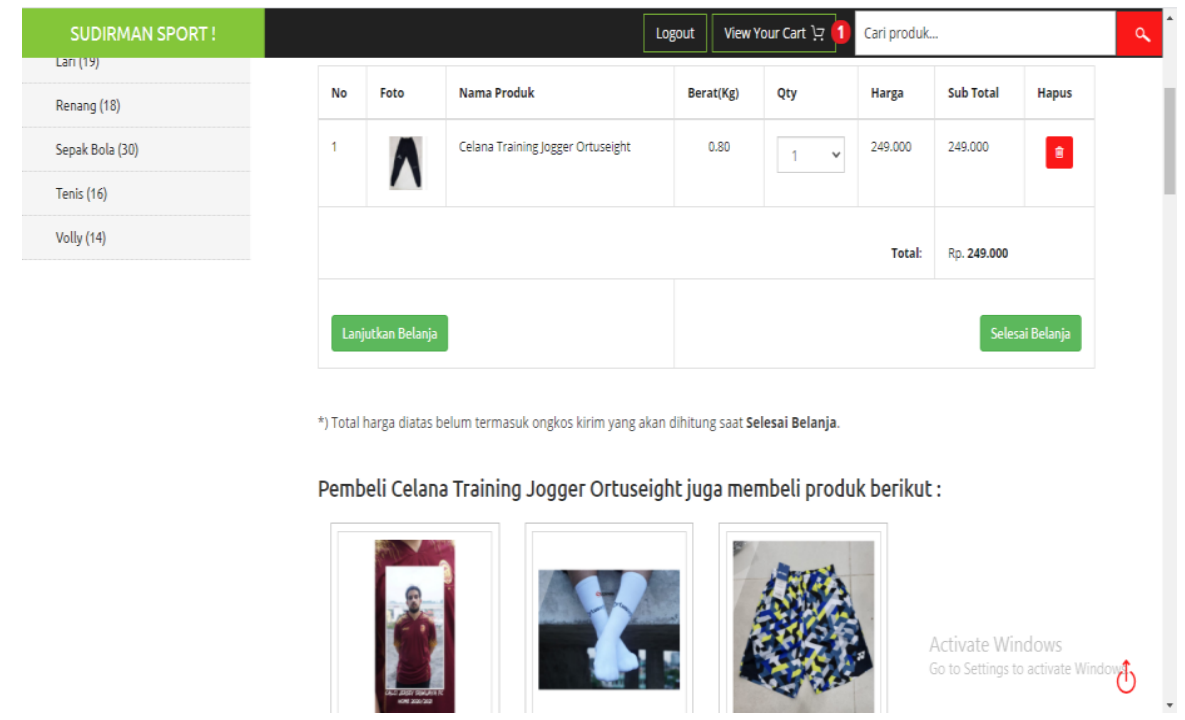

Gambar 11. Tampilan Rekomendasi Apriori

\section{Kesimpulan}

Berdasarkan dari hasil penelitian yang ditulis penulis telah dilakukan, maka penulis menarik kesimpulan sebagai berikut:

1. Terciptanya aplikasi e-commerce berbasis website.

2. Berhasilnya diimplementasikan sistem rekomendasi menggunakan metode algoritma apriori di aplikasi e-commerce berbasis website berdasarkan proses algoritma apriori dari data transaksi penjualan bulan Agustus dengan minimal support 3\% dan minimal support 50\%.

3. Memperluas ruang lingkup pemasaran produk sehingga dapat meningkatkan omset penjualan.

\section{Referensi}

Yudanar, A. F.; Fitriasih, S. H.; Hasbi, M. Rekomendasi Barang Di Toko Elektrik Menggunakan Algoritma Apriori. J. Teknol. Inf. Dan Komun. TIKomSiN 2020, 8 (2). https://doi.org/10.30646/tikomsin.v8i2.499.

Fitrina, N.; Kustanto, K.; Vulandari, R. T. Penerapan Algoritma Apriori Pada Sistem Rekomendasi Barang Di Minimarket Batox. J. Teknol. Inf. Dan Komun. TIKomSiN 2018, 6 (2). https://doi.org/10.30646/tikomsin.v6i2.376.

Kusrini and Emha Taufia Lufthi. Algoritma Data Mining; Andi: Universita Anikom Yogyakarta, 2019.

Dewantara, H.; Santosa, P. B.; Setyanto, N. W. Designing Applications Data Mining With The Apriori Algorithm To Frequency Market Basket Analysis On Sales Transaction Data. 12.

Haerulah, E.; Ismiyatih, S. Aplikasi E-Commerce Penjualan Souvenir Pernikahan Pada Toko "Xyz." 2017, 4 (1), 5.

Anhar ,ST. Panduan Menguasai PHP \& MySQL Secara Otodidak; Mediakita: Jakarta, 2010. 
Handayani, S. Perancangan Sistem Informasi Penjualan Berbasis E-Commerce Studi Kasus Toko Kun Jakarta. Ilk. J. Ilm. 2018, $10 \quad$ (2), 182-189. https://doi.org/10.33096/ilkom.v10i2.310.182-189.

Swara, G. Y.; Kom, M.; Pebriadi, Y. Rekayasa Perangkat Lunak Pemesanan Tiket Bioskop Berbasis Web. 2016, 4 (2), 13.

Mukhtar. Metode Praktis Penelitian Deskriptif Kualitatif; GP Press Group: Jakarta Selatan, 2013.

Sandi Fajar Rodiyansyah, 2015, Algoritma Apriori untuk Analisis Keranjang Belanja pada Data Transaksi Penjualan, Infotech Journal.

Susanto, Azhar, 2013, Sistem Informasi Akuntansi. Bandung, Lingga Jaya.

Sutabri, Tata, 2012, Konsep Sistem Informasi, Yogyakarta, Andi.

Vivekananth, P, 2012, Different Data Mining Algorithms: A Performance Analysis. International Journal of Emerging Trends and Technology in Computer,Vol. 1, 79-84.

I. Kurnawan, F. Marisa, and P. Purnomo, "Implementasi Data Mining Dengan Algoritma Apriori Untuk Memprediksi Tingkat Kelulusan Mahasiswa,” J. Teknol. dan Manaj. Inform., vol. 4, no. 1, 2018.

L. Kurniawati, A. E. Kusuma, and B. Dewansyah, "Implementasi Algoritma Apriori Untuk Menentukan Persediaan Spare Part Compressor," Computer

\section{Copyrights}

Copyright for this article is retained by the author(s), with first publication rights granted to the journal.

This is an open-access article distributed under the terms and conditions of the Creative Commons Attribution license (http://creativecommons.org/licenses/by/4.0/) 